\title{
The Role of Non-Governmental Organizations (NGO's) in Shaping Environmental Policies
}

\author{
Aswin A. Azis \\ International Relations Department \\ Brawijaya University \\ Malang, Indonesia \\ a.azis@ub.ac.id
}

\begin{abstract}
In recent decades Non-Governmental Organizations (NGO's) have given a major contribution in raising many environmental issues to the forefront of society. Many scholars and analysts have stressed the potential role played by NGOs in shaping public perceptions and creating narratives and values about the environment. Plenty of studies has also shown the growing influence of NGOs' international fora and their positive contribution to the development of an international environmental protection regime. However, some scholars have also doubt that NGOs have succeeded in forcing governments of nation-states to adopt and comply with more vigorous environmental positions. Their role in environmental policy changes and policymaking is still very much contested. This essay argues that the relative success of NGOs in international fora does not necessarily coincide with their domestic counterpart, particularly in environmental policymaking. That even though NGOs have played quite a significant role in creating awareness in environmental issues over the past few decades, at the nation-state level their influence in shaping environmental policies might not be as much as many as hoped for. They have played a huge role in environmental advocacy as well as service delivery but not so much on pushing changes in environmental policies, especially in developing countries. Hence, the essay attempts to compare the role of NGOs in international fora in encouraging changes of global environmental standards and regimes with its effort in environmental policymaking at the domestic level. It put forward the essential component of NGO's advocacy arguing that it has a key role not only in encouraging changes in public attitudes towards environmental issues but also to help shape government environmental policies.
\end{abstract}

Keywords-NGOs, environmental policies, advocacy

\section{INTRODUCTION}

In recent decades Non-Governmental Organizations (NGO's) have given major contributions to raising many environmental issues to the forefront of society. Many scholars and analysts have stressed the potential role played by NGOs in shaping public perceptions and creating narratives and values about the environment. Plenty of studies has also shown the growing influence of NGOs' international fora and their positive contribution to the development of international environmental protection regimes. However, some scholars have also doubt that NGOs have succeeded in forcing governments of nation-states to adopt and comply with more vigorous environmental positions. Their role in environmental policy changes and policymaking is still very much contested.

This essay argues that the relative success of NGOs in international fora does not necessarily coincide with their domestic counterpart, particularly in environmental policymaking. That even though NGOs have played quite a significant role in creating awareness in environmental issues over the past several years, at the nation-state level their influence in shaping environmental policies might not be as much as many as hoped for. They have played a huge role in environmental advocacy as well as service delivery but not so much on pushing changes in environmental policies, especially in developing countries. Hence, the essay attempts to compare the role of NGOs in international fora in encouraging changes of global environmental standards and regimes with its effort in environmental policymaking at the domestic level. It put forward the essential component of NGO's advocacy arguing that it has a key role not only in encouraging changes in public attitudes towards environmental issues but also to help shape government environmental policies.

\section{THE RISE OF NGOS: GROWING INFLUENCE}

The world is facing serious and, in some cases, potentially irreversible environmental changes. NonGovernmental Organizations (NGOs) have raised many environmental issues to the forefront of society, in which they further argue that these challenges not only impede sustainable development efforts around the world but also frustrate and undermine global efforts to reduce poverty.

In regards to the argument above, this essay argues that NGOs have played quite a significant role in 
environmental issues over the past few decades, however, their influence in shaping environmental policies at the national level may not be as great as expected. Henceforth, Environmental NGOs should pay more attention to their advocacy role without having to leave its role on service delivery. Edwards (2004) believes that NGOs play a vital role in the civil society concept. By organizing resistance and providing alternative solutions to social, economic, and political problems, NGOs provide a yardstick for social movements and a practical framework for social, economic, and political problems [2].

Non-governmental organizations or commonly call NGOs have become dominant in international development since globalization increased massively. The term NGO encompasses a huge category of civil society groups and organizations.

For example, the World Bank (1995) defines NGOs as private organizations that focus on activities to alleviate suffering, protect the interests of the poor, children, and marginalized people, including protecting the environment by providing basic social services. or embodying community empowerment. [3]. A World Bank Key Document regarding Working with NGOs, explain more about the term of NGOs. This document emphasizes that NGOs can be independent non-profit organizations, typically value-based organizations that depend (in whole or part) on both donations and volunteer service. Altruism and voluntariness remain the most important key characteristics of NGOs, even NGOs themselves must become more professional.

In the above-mentioned document, not only the concept of NGO is mentioned, but also the development of NGOs. NGOs in developed and developing countries have experienced rapid growth.

It is estimated that since the 1970 s more than 15 percent of all foreign development aid has been distributed through NGOs, which means that about $\$ 8$ billion goes to NGOs. The World Bank adds that there are around 6,000 to 30,000 national NGOs in the developing world, while the population of community organizations in the developing world is estimated at hundreds of thousands [3].

The impact of NGOs, therefore, extends beyond their increasing numbers. Government and international agencies now afford them a broader role. Edward and Hulme explained how New Policy Agenda (NPA) has arisen with integrating markets and liberal democratic politics. In this case, NGOs are simultaneously assessed as market-based actors and place, and as components of 'civil society. Thus, the rise of services provided by NGOs, regarding environmental relevance including agricultural extension and marketing is seen as part of the means of the state's privatization, although NGOs' have a nonprofit basis. This situation is commonly known as "filling the gap" and occurs when states, especially in the south, are not capable enough to maintain public services or have to reduce them as part of a structural adjustment or a "reform package" donor-funded [4].

Even though corporations and governments see Environmental NGOs as part of the economic formulae for growth and profitability especially within the third world and developing countries, they are both philosophically at loggerheads, because NGOs advocate sustainability and equality such as the balance between social and environmental needs, whereas governments and corporations are mainly concerned about economic growth and the rate of profit respectively, and more often than not environmental concerns for them are seen as threats to their basic economic principles, hence corporations and governments may use rational arguments against or play down the environmental issues of the day or disguise economic interests behind environmental reasons.

A good example of this is occurring at the moment within Australia, the John Howard lead government and the Uranium Industry are trying to persuade the Australian public to take up Uranium as an alternative clean energy resource to replace their current coalpowered electricity stations and therefore reduce Australia's carbon dioxide emissions [5], however, the environmental and economic costs related to Uranium being used as an energy resource far outweighs its benefits. Therefore, I believe Uranium is being advocated because only its short-term to medium-term economic benefits are being considered in terms of immediate growth and profitability, however, the mining, processing, disposal and trading issues surrounding Uranium are being overlooked in favor of economic interests [6].

Many scholars believe the two most common goals of both Environmental Lobby and Direct-Action Groups is to create greater environmental awareness and change; however, the fundamental differences between the two groups are how they go about achieving these, regardless of whether they are an international, national or local organization. For example, Greenpeace International will typically reveal crucial environmental problems or issues through the media and challenge corporations and governments on their environmental record or through a significant present-day issue and try to force them to adopt and act upon better and safer environmental practices. Greenpeace believes they can create better environmental change and awareness through aggressive, but non-violent action against the richer and more powerful sectors of society. In contrast, Direct Project Groups promote and act upon environmental programs, such as Saltwatch Australia for example, which monitor salinity levels within certain habitats that have been stripped of native flora to make communities aware of the inland salinity problems [7] and to ultimately motivate the local governments to 
take appropriate action by lowering the water table and salinity through the use of salt-tolerant plants which will hopefully lead to, over time, the planting and growth of the original plants within those habitats. The two basic groups of environmental NGOs are explained in more detail in a compilation by Ali Mostashari (2005), which divides NGOs into two main groups: operational NGOs and advocacy NGOs. This can be defined as the choice between small changes achieved directly through projects and large changes achieved indirectly through influences on the political system, but here again, I believe that the two categories remain regardless of the size or scope applied by various environmental NGOs [8].

Another Environmental NGOs classification however made by Alan Thomas (2001) who stated that there are 4 types of environmental NGOs; first, are international environmental NGOs typified by Greenpeace, second, are northern-based development agencies such as Oxfam, the Lutheran World Federation, and so on [4]. Those generally have branches in the under-developing or developing countries. The majority of these NGOs are occupied with country advancement projects. In recent years, they have either added environmental viewpoints to their ventures or simply discovered such aspects to be a vital piece of their work. Third, at the highest level which is a national stage, there are public interest researches or campaigning associations. Some, relatively few, are Western-style conservationist organizations, such as Okavango Wild Life Society (OWLS) based in South Africa and Nigerian Conservation Foundation.

The fourth types are native or indigenous and national (and province) service-based NGOs, which mainly focus on welfare and rural development. A portion of these associations focuses on specific constituencies, like women and poor villages, while others embrace a participatory style and endeavor to develop local enrollment. Numerous worldwide NGOs have moved from arranging projects themselves to working through an organization with NGOs of this type [4]. Again, these four NGO groups can be reduced to two basic categories; Lobby and Direct-Action Groups, or Advocacy and Operational Groups.

NGOs do not have a significant contribution until the late 1990s. But in their early years, NGOs could have potentially contributed to the effectiveness of regional and domestic governance. For example, until the late 1980s, environmental awareness in Europe was quite low, and only in the early 1990s did it spread around the world. According to a Gallup study conducted for UNCED, global concern has grown, yet transboundary and global concerns have received little attention. Individual factory relocations, rather than regional planning, remained extremely problemspecific in public opinion [9].
The increasing diversity of civic engagement on environmental issues was another significant advance in the decade. Although technically their objectives are not the "environment", the organizations that work for poverty reduction, human rights, rural development projects, the rights of indigenous peoples and women, as well as for world peace, are increasingly collaborating with environmental organizations to influence policy [1]. A good example is the Jabiluka Action Group who was a mixed and ad-hoc organization spread right across Australia fighting against the Uranium Mine in Jabiluka and campaigning for the preservation of the Mirror peoples' land rights who reside in that area of the Northern Territory [10]. Another example is the recent World Summit on Sustainable Development (WSSD) in Johannesburg, which brought together a diverse group of thematic non-governmental organizations (NGOs). In contrast, the NGOs that participated in the 1992 Earth Summit in Rio were mostly environmental NGOs. These disparate groups are coming together for several reasons. Globalization's consequences on jobs, health, and the environment are a well-known topic that brings together human rights organizations, labor unions, and environmental organizations [1]

Because the environmental NGO network is so large, there is no true shared solidarity. There are tens of thousands of environmental non-governmental organizations (NGOs). Many Northern NGOs work on local concerns in the north, participate in worldwide campaigns, and oversee conservation and development initiatives in the south. Only after the United Nations Conference on Environment and Development (UNCED) did NGOs in poorer nations become politically relevant. Most are just concerned with local concerns, leaving transboundary and global matters to northern advocates [9].

Politically, NGO efforts on the ground are considerably simpler in the north, where government decision-making is more transparent. NGO campaigners in democracies faceless personal danger and employ public education campaigns to directly affect nations, especially if individual preference shifts are communicated through elections. Strong northsouth ties, according to Keck and Sikkink, are essential for effective NGO engagement in the South. Effective NGO pressure on developing country governments is based on well-planned campaigns involving Northern and Southern NGOs, as well as pressure on important influential international institutions and Northern governments, such as attempts to reverse Brazilian government policies that played a role in Amazon deforestation [9].

The "Boomerang effect," as described by Keck and Sikkink, necessitates widespread public concern in powerful political arenas. For example, when NGOs were able to cooperate with US domestic organizations to persuade the US Congress to use its authority over 
the World Bank to impose pressure on the Brazilian government, Brazilian rain forest policy changed. Since the World Bank was ultimately subject to pressure from the US government, and because the World Bank is indeed responsible in part to NGOs and required to include them in its operational activities for service provision, prosperous NGO environmental campaigns targeted against the World Bank were successful [9].

Nonetheless, non-governmental organizations (NGOs) do not always contribute to sound environmental decisions. These leading civil society organizations are not immune to the challenges of legitimacy, transparency, and accountability, which NGOs often pose vis--vis government and business. They are also not universally effective, receptive to new ideas, or eager to work with others. This flaw can expose NGOs to attacks from government bureaucracies, politicians, and the media, as well as jeopardize their reputation with many financiers [1]

The effect of NGOs on international environmental politics and links is restricted to tactical links at most. Their campaigns are essentially opportunistic, as they plan their victories around brief windows of opportunity when political influence becomes available [9].

\section{NGOS' INFLUENCE IN ENVIRONMENTAL POLICIES}

GOs are involved in global environmental policy in a variety of ways: they seek to raise awareness of environmental issues; pressure state decision-makers in hopes of influencing national and foreign environmental policies; organize boycotts to change environmentally harmful business practices; contribute to global environmental negotiations, and they help monitor and also implement international treaties. It is important to remember that these operations are carried out by various non-governmental organizations (NGOs) in various political forums, each with its own set of objectives, methods, and political dynamics [11].

Thus, it might be said that NGOs still very much depend on the political arena where they openly act upon their environmental policies including their domestic ones in front of the media and thus the public as well.

Historically, environmental policies were mostly centered on regulatory instruments (i.e., command and control). This was due to the perception that environmental challenges were technological challenges that could only be addressed by managing a small number of major enterprises [8].

As a result, governments in several wealthy nations established autonomous yet technically focused environmental committees. Many emerging countries have adopted this strategy in some form or another.

However, since the environment has become one of the three pillars of sustainable development and worldwide ecological challenges have taken center stage in international politics, significant new advances in the formulation of environmental regulations and, as a result, in environmental governance have happened. Environmental issues are now viewed as a critical policy problem affecting all individuals, organizations, private businesses, and governments [8]. In legitimizing the environment as a policy issue, ecological modernization has contributed to what Heyzer [12] argues has been ' a reconsideration of the existing participatory practices' so that they increasingly include environmental groups [13].

The environmental issues that emerging countries face are significant. Classical environmental concerns, such as pollution, must be handled, but new forms of environmental challenges, such as global environmental problems, generated by modern lifestyles, must also be addressed. Developing countries have a significant problem as a result of this dual character. It demands creative environmental policies as well as an understanding of the region's strengths and limitations, such as the utilization of modern technology and policy lessons from rich nations to offset developing nations' lack of experience, funding, and equipment. In reality, developing nations cannot manage to adopt the same path as wealthy ones, i.e., pollute first, clean up afterward. It's simply too expensive. A wide range of clean technology is now available, as well as priceless policy lessons from which to learn about the best and least successful policies and instruments.

\section{NGOS DEVELOPMENT IN INDONESIA AND THEIR APPROACH TO ENVIRONMENTAL ISSUES}

There has been growing awareness of the importance of non-government organizations (NGO's) in Indonesia in recent years. Such interest appears to be motivated by two broad sets of concerns. The first is a quest for more progressive and participative social and economic development models that place a higher focus on people's definitions of their needs and strengthen their ability for self-management. The second focuses on non-governmental organizations (NGOs) as accelerators for strengthening democratic principles and processes in Indonesian society and politics [14].

During the late 1960s and early 1970s, development-oriented NGO's arose about the impact of rapid economic growth on the lower classes of society, while issue-oriented NGO's arose in opposition to macro-economic growth that profited the elite but exclude those at the grass-roots level of society from the decision-making process [15].

The cyclical nature of government attitude toward NGOs was evident throughout the 1980s; the government appeared to take a more relaxed stance, adopting a "live and let live" mentality. Some in the national government understood that, in a time of dwindling resource availability, NGO operations were important and beneficial, and their operations have 
been absorbed into official activities, with or without acknowledgment. However, NGOs did not become an extension of the government as a result of their tighter collaboration with the government [16].

Furthermore, various issues on environmental problems have been arising in some parts of central and east Indonesia during the decade. In previous years, the environmental destruction and land user problems have been seen as a direct result of timber concession or transmigration programs in Kalimantan and Irian Jaya. In addition to that those environmental problems have gained national and international attention. Simultaneously, issues on the subversion of native people and minor cultures in the hinterland of Kalimantan and Papua (Irian Jaya) have become focal issues that are also being confronted by the NGOs.

These increasing problems have, however, less significance in the context of the stunted growth of NGOs in Central and Eastern Indonesia alone. Indeed, two tendencies can be observed in this progress. Firstly, the increasing development problems in Eastern and Central Indonesia have stimulated the emergence of new NGOs in Java whose programs spread to outer islands. Secondly, due to the situation where many international development agencies began to direct their program to the eastern islands ('Go to the East'), the growing issues and problems in outer Java have provoked also the established (big) NGOs in Java to expand their activities to outer islands [17].

While still accepting assistance from NGOs, the Indonesian government tried to prevent the emergence of popular participation based on groups with genuinely independent strength. One strategy for neutralizing NGOs is for the government to establish parallel structures aimed at mobilizing 'target groups' such as women, youth, and farmers. Generally, these have proved to be empty shells without popular support. Excessive dependence on 'functional groups' and Government NGOs (GONGOS) is counter-productive to solving serious social, economic, and environmental problems of rising relevance to an increasingly wide range of decision-makers, notwithstanding their importance as instruments for political control. This inconsistency appears to be crucial to understanding the muddled semi-public discourse in Indonesia regarding "participation," "political openness," and other topics [18].

In contrast to the official development approach which emphasizes infrastructure development, commercial gain, and creating industrial development opportunities for exporters, the NGO development vision generally includes a commitment to the social and economic welfare of the community [19]. NGOs argue that this approach embodies a strong political and economic sense of democracy based on participation from below, participation with and by the people. In addition to aiming to improve the quality of life of the poor, NGOs say they seek to remedy social injustices by strengthening the capacity of people in developing countries to facilitate structural change to allow their indigenous communities and organizations to focus on their own needs and priorities [19]. However, in this point of view, the differences between NGOs in developed countries, for example, in Japan and developing countries such as Indonesia is quite obvious. One difference is in how they generate donations. Supporter fees, subsidies, and other sources of funding were used by Japanese non-governmental organizations. In Indonesia, NGOs are compensated for the services they provide as part of a development initiative. In this regard, there is a significant contrast between them, and in Indonesia, 'NGO is business' [20].

The goal of NGOs has always been to address underlying power and resource gaps by speaking out in support of certain groups, mobilizing to protect the interests of disadvantaged people, and urging the government to change policy. Many of the world's largest and most respected non-governmental organizations (such as Save the Children and Oxfam) were created and formed against government policy and entrenched interests. However, if non-governmental organizations (NGOs) continue to rely on government funding, their positions will be called into doubt. Furthermore, a climate in which non-governmental organizations compete for government funding is unlikely to generate the collaborative ties that are the foundation of effective policy partnerships [2]. In the case of Indonesia, increased funding agency independence might jeopardize the efficacy, legality, accountability, and sustainability of local NGOs. Moreover, as the emphasis has turned away from NGOs as a magic bullet for reducing poverty, interest in NGOs has started to take on a more critical, analytical tone among certain development experts [2]. Within NGO work, problems of efficiency, accountability, and effectiveness are being given more serious consideration [21].

One of the critical questions is whether the role of NGOs is a catalyst for core change to help create a better society and life for individuals or do they just deliver a service to only help remedy the symptoms? This question is highly relevant and important in the current political atmosphere for NGOs, particularly the ones in developing countries because they have to see whether their heavier reliance on government support is leading them to be ineffectual in achieving their goals for social change or not. To address that issue, they would have to go back to their original objectives and values and act upon them appropriately. This is exemplified by NGOs in developed countries; they are putting remunerated groups of people out into the public to promote their causes and as a result attract members of the public to become paid members. As a consequence of increased members, they can increase their funding through the public directly and rely less on the charity of government agencies and act upon their core principles of social change more freely 
regardless of whether corporations or governments oppose them or not.

Finally, NGOs are growingly being seen as just one type of development actor within a larger institutional landscape that contains the state and the market, and where ideas about promoting synergy are slowly taking precedence over rather mechanistic conceptions of comparative advantages and the dogma of privatization policy [21]. But a more realistic assessment of what NGOs can and cannot accomplish is in the air. However, little attention has been paid in either the development or management literature to the topic of whether such non-government organizations face a unique set of organizational issues [21].

Since the crisis, the tendency of greater advocacy role especially in challenging neo-liberalism and injustices contributed by global economics has been taken up by some of Indonesia's NGOs. At the national level, some environmental cases have been a selfevident critique of international financial institutions and their failing pure economic policies and as a consequence are labeled as successes. The rejection of the Lore Lindu Dam in Central Sulawesi and the Kalimantan Industrial Forest Plantation project are two instances of these victories [22]. However, these lobbying efforts have not yet progressed to the point where they may spark the establishment of a movement to openly attack international financial institutions such as the World Bank and the Asian Development Bank.

One reason might be that most protesters in Indonesia at the time did not consider being an activist who understood the Development Banks and their relationship to environmental concerns to be vital. The Anti-Debt Coalition Movement, founded at the Consultative Group on Indonesia's (CGI) final Annual Meeting in 2000, awakened many people's eyes to the gravity of Indonesia's debt issues, which have grown dramatically due to a lack of oversight from civil society. In that year, the Asian Labor Network campaigned for the formation of a people's movement that opposes the role of foreign financial institutions in Indonesia's debt crisis [22]

Collaboration between Indonesian advocacy NGOs and foreign NGOs working on problems like the environment and human rights, on the other hand, might easily lead to confrontation with the government. The basis of development concerns has shifted from community development to structural challenges. The government, on the other hand, argues that NGOs are not political parties and that they must refrain from advocating on subjects that the government considers being political party concerns. Political parties in Indonesia, on the other hand, are hesitant to confront the contentious problems that advocacy groups have targeted. Not all non-governmental organizations (NGOs) work with funding agencies to promote contentious environmental and development concerns in the country. Much bigger and established NGOs forgo advocacy actions, preferring to focus on their original objective of community development, depending on the political climate of the nation. This explains why NGOs seem to gain more successes at the international level, or in countries where democracy has already gained a certain level.

\section{CONCLUSION}

In the context of a constructive, self-critical, and analytical framework Environmental NGOs will be able to go forward more effectively to help create social change and challenge the injustices brought about, for example, by the practice of pure economic rationalization perpetuated by many conservative or neo-liberal governments and corporations around the world. To achieve this both Lobby and Direct-Action Environmental NGOs must continually and independently demonstrate through real-life examples and sound arguments that only sustainable economic and ecological practices will create a better society as a whole and life for the individual in both developed and developing countries. Hence, learning from the success of global NGOs in pushing the environmental issue at the multinational forum, environmental NGOs at the national level must strive to push the same agenda and make sure what was successfully achieved at the global level can be incorporated into domestic environmental policies.

\section{REFERENCES}

[1] UNDP, "Awekening Civil Society," in World Resources 20022004: Decision for the Earth: Balance, Voice, and Power, World Resources Institute, 2003.

[2] D. Hulme dan M. Edwards, NGO's States and Donors: Too Close for Comfort? New York: St Martin Press in association with Save the Children Fund, 1997.

[3] World Bank, "Working with NGOs: A Practical Guide to Operational Collaboration between the World Bank and NonGovernmental Organization," Operation Policy Department, Washington, 1995.

[4] A. Thomas, S. Carr, dan H. D., Environmental Policies and NGO Influence: Land degradation and sustainable resource management in sub-Saharan Africa. London: Routledge Research Global Environmental Change, 2001.

[5] "Research Activities FY 2003," 2003.

[6] Howard, "Howard Welcomes New Debate on Nuclear Power," The Age, 2005. [Online]. Available at: http://www.theage.com.au/news/National/.../2005/06/09/1118 123962801.html/.

[7] "Salinity Levels in Victorian Soil." [Online]. Available at: www.saltwatch.org.au/.

[8] A. Mostashari, "An Introduction to the Non-Governmental Organization (NGOs)," Iran. Stud. Gr. MIT, 2005.

[9] P. Haas, "Lessons from Environmental Governance for Debt Forgiveness," in Sovereign Debt: Origins, Management, and Restructuring. London: Royal Institute of International Affairs, 2005. pp 255-277.

[10] SEA US, “Jabiluka Action Group (GAP)," SEA US. [Online]. Available at: www.sea-us.org.au/radactshow/index.html/ .

[11] M. Betsill dan E. Corel, NGO Influence in International Environmental Negotiations, vol. 1, no. 4. MIT, 2001. 
[12] N. Heyzer dan J. . Riker, Government-NGO Relations in Asia: Prospects and Challenges for People Centred Development. Houdmills: Macmillan Press Ltd, 1995.

[13] P. Rawcliffe, Environmental Pressure Group in Transition. Manchester: Manchester University Press, 1998.

[14] P. J. Eldridge, Non-Government Organizations and Democratic Participation in Indonesia. Kuala Lumpur: Oxford University Press, 1995.

[15] H. Anderson, "Good Governance and NGOs in Contemporary Indonesia," Monash University,2004.

[16] S. Cleary, The Role of NGOs under Authoritarian Political Systems. Houdmills: Macmillan Press Ltd, 1997.

[17] K. Sinaga, NGOs in Indonesia: A study of the Role of Non Governmental Organizations in the Development Process. Saarbrucken: Verlag fur Entwicklungspolitik, 1995.
[18] A. Budiman, State and Civil Society in Indonesia. Victoria: Aristoc Press Pty Ltd, 1990.

[19] S. MacPherson dan H. Wong, Social Development and Societies in Transition. Aldershot: Ashgate, 1998.

[20] A. Tomomatsu, "Development Partnership between Japan and Local NGO: A Case Study in Indonesia," Ritsumeikan Int. Aff., vol. 2, hal. 97-114, 2004.

[21] D. Lewis, The Management of Non-Governmental Organizations (NGOs): An Introduction. London: Routledge, 2001.

[22] V. Q. Perez, "Building NGO Capacity Is Key to ADB Advocacy," in Forum Briefer 01-05, 2001. 